\title{
THE CASE FOR GOVERNMENT LIFE INSURANCE
}

\author{
MAURICE TAYLOR*
}

A proposal for nationalizing life insurance sounds far less heretical in I934 than it would have in 1929. Events have presented themselves to the American scene during the past five years of such a character as to undermine blind confidence in private enterprise and to cause the population at every level to look toward the federal government for aid in the solution of its present difficulties and the prevention of their recurrence. Much less attention is now paid to the various shibboleths seeking to apotheosize private enterprise while debasing everything that savors of an extension of the governmental function. Nor has this change in public sentiment remained in the realm of the ethereal. On the contrary we find it manifested in the actual entry of the government on many fronts into what was once considered the sacred domain of private business.

Insurance under governmental auspices is, of course, no new phenomenon. There is probably no country of importance on the face of the globe today which has not participated in conducting plans for the distribution of several sorts of risks and the payment of losses. Even in the United States, where progress in the socialization of its insurance mechanisms has been least, there has been a rapid advance, particularly in the casualty field. In life insurance we have federal war-risk insurance and the Wisconsin Life Fund.

One potent factor making this question of real interest today is the rediscovery of the consumer in American life. Under the NRA he has been accorded some recognition, feeble though it has been. When action replaces lip service and he is placed on a par with the other factors in production and distribution, better goods and services at cheaper prices may be hoped for. This should be as possible in life insurance as in any other field.

Our history has been marked by a blind opposition to the entrance of government into the economic life of the people. The narrow philosophy of the relationship between the state and business that existed in this country up to the latter part of the nineteenth century served to lay the groundwork of a tremendous body of

- A.B., 19r6, M.A., 1925, Ph.D., r931, Harvard. Director, Jewish Family Welfare Association, Boston, since 1923. Formerly special lecturer on the Administration of Social Agencies, Harvard, on Insurance, Simmons College School of Social Work; lecturer on Social Insurance, Division of University Extension, Massachusetts Department of Education, and Twentieth Century Adult Education Center, Boston. Contributor to periodicals of numerous articles on social service, relief, and insurance problems. Author, The Social Cost of Industrial Insurance, Alfred A. Knopf, Inc., New York, I933. 
vested interests which makes any proposal of this nature unduly difficult of achievement. It is a remarkable fact, however, that the extension of federal activity has been accomplished under the administration of both major political parties-although sometimes, it may be said, at a cost to the many for the benefit of a few. However, we do not intend to dwell on this subject unduly. An irrefutable answer to the objection may be found in that were the government to divorce itself entirely from private enterprise, the first to complain and those who would stand to lose the most would be those who now enjoy in largest measure the benefits of the quintessence of government participation, namely, our high protective and ruinous tariffs. We may, therefore, dismiss this objection to government operation of life insurance as specious. The disadvantages of the proposal can and must be argued on other grounds.

\section{"States Rights" and the Necessity for Federal Operation or Control}

When we refer to government operation of the life insurance business what we have in mind is the federal and not state government. One of the main checks to the proper conduct of this important branch of affairs and a serious obstacle to securing to the great bady of policyholders a more equitable and a less costly system of protection is the chaos introduced by insisting that each of the forty-eight states should have independent jurisdiction not only within its own borders, but throughout the length and breadth of the land'wherever the companies incorporated by it operate. For this condition we have to thank the Supreme Court which in $1869^{1}$ by a strained and strange legal fiction held that insurance is not interstate commerce. It is explained ${ }^{2}$ that one of the reasons for the original decision that insurance is a matter of state concern only was the immediate fact of the absence of federal machinery for the control of corporations operating in a number of states. Despite the growth of such mechanisms the Court has not changed its opinion in subsequent decisions.

Whatever may be the advantages of states' rights in other directions, it is clear that in the field of insurance this doctrine has nothing to commend it. The principles of insurance are universal and, subject to broad limitations, not advantageously amenable to sectionalism. For the forty-eight different kinds of laws, prohibitions, interpretations, and administrations, the insured American' public has had to pay a tremendous toll. Centralization on a national scale is necessary whether it comes through government operation or simply regulation. There will thus be achieved uniformity in place of conflicting and overlapping jurisdiction and discrimination between groups of policyholders. The bogey of retaliatory legislation will disappear together with the ill effects of local prejudice and ignorance.

The more local the legislation the less broad is it likely to be in its social outlook. State legislation is apt to be better than municipal, and, similarly, federal legislation

${ }^{1}$ Paul v. Virginia, 8 Wall. I83 (U. S. 1869). Cf. Keezer \& MAY, The Public Contror of Business (1930) 213.

${ }^{2} I d$. at $2 \times 4$. 
in comparison with state. This is equally true in the sphere of administration. Since insurance of all kinds, and particularly life insurance, is interstate in most of its manifestations, the dictum of the Supreme Court to the contrary notwithstanding, leadership of the widest scope is essential, and this is most reasonably lodged in the federal government.

The most powerful and practical obstacle to government operation of insurance is the force of vested interests. These lie perhaps as much with the states with respect to their powers of regulation and taxation as with the companies. "Clear recognition of this fact was made by the Supreme Court in a case calling for reconsideration of the insurance business. Justice McKenna, referring to a series of cases which had adhered to the doctrine that insurance companies are engaged in intrastate commerce, said, 'To reverse the cases ... would require us to promulgate a new rule of constitutional inhibition upon the states and which would compel a change of their policy and a readjustment of their laws. Such a result necessarily urges against a change of decision. ..." "3 The results of such adherence to the status quo, however, are serious enough to warrant a change in this view, and if the Supreme Court continues inflexible in its outlook toward modern conditions, there is sound reason for the proposal to amend the Constitution to bring life insurance under the control of the federal government.

\section{The Problem of Compensating Private Interests}

The problem of vested interest in life insurance is different from that of almost any other business due to its widespread mutualization. It is a field in which the general consensus of opinion is that it should be non-profit making. It is characterized by a degree of public interest and is linked to the public welfare to an extent not exceeded by any other activity under or outside of government control. It is, therefore, a type of transaction which is peculiarly susceptible of government operation.

Of the 328 life insurance companies which reported their figures to The Spectator Company of New York in I933, 262 are stock and only 66 mutual. This would seem to indicate the reverse of the statement concerning life insurance as a nonprofit making venture. However, the gross assets of the 262 stock companies total less than four and one-half billion dollars while those of the 66 mutual companies amount to nearly $16 \frac{1}{2}$ billion dollars, or 79 per cent of the total gross assets of approximately $2 \mathrm{I}$ billion dollars. These figures are significant when the question of indemnification is considered in connection with the government's taking over the business.

In the stock company, the property is vested in the stockholders; in a mutual company it is vested in the policyholders. But even in a stock company the gross assets are only in small measure the property of the stockholders. The bulk of them

3Id. at 215, quoting from New York Life Insurance Co. v. Deer Lodge County, 23I U. S. 495,502 (rg13). 
are liabilities in favor of the policyholders. Capital, even in a stock life insurance agency, is contributed for the most part not by the stockholders but by the policyholders. The total stated value of the stock of the 262 companies is $\$ 162,022,000$. Assumption of their business would involve roughly the reimbursement of the fair value of the stock at the time of transfer of control plus whatever sums are possessed by them over and above the sums actuarially necessary to protect the insurance contracts and dividends declared on them. The government would then assume all of the liabilities and take possession of the assets. ${ }^{4}$ In the case of mutual companies the procedure would likewise be the assumption of all liabilities and the taking over of the assets.

The officers and employees of the companies have no vested interest recognizable by the government in compensation proceedings. However, it is this group alone which stand to lose by the transaction and from them would come pressure against it. Companies are, however, neither formed nor conducted for the benefit of either, and if it were decided that federal monopoly were desirable these individuals would have to capitulate in the interest of the general public welfare. Many, of course, would transfer their talents to the public service, although very likely at a material financial sacrifice. The vested interest problem in life insurance exists, therefore, mainly in the protection of current income rather than in the reimbursement of capital. This would by no means lessen the pressure against the proposal, the accomplishment of which would involve us in a cost which would not even approximate the social advantages accruing therefrom.

\section{- Suitability of Insurance Business to Government Operation}

All this assumes, of course, the establishment of a public monopoly of all life insurance as in Italy, Uruguay, and Costa Rica. The government might make participation compulsory for all, or it might dispense protection only to those who chose to avail themselves of its facilities. It might also enter into the business on a competitive basis with the already existing companies as in New Zealand, Belgium, Denmark, and Wisconsin. A third plan might be found in an extension of the Massachusetts Savings Bank Life Insurance system on a monopoly basis but under private control, or the government might limit its activities to insurance for smaller amounts by nationalizing the present industrial insurance business while leaving insurance of larger sums to the private companies. ${ }^{5}$ It would thus confine itself exclusively to the insurance problem of the lower income classes. Some of these alternatives will be touched on briefly. It is manifestly impossible, however, within the limits set for this paper to outline the pros and cons so essential to an adequate discussion of the subject.

There is no legal restraint which would prevent the government from entering

\footnotetext{
- Recent discussions of nationalization by the British Labour Party suggest not a lump sum payment but a 25-year annuity involving a lesser amount in total.

The ideal place for burial insurance is in a national social health insurance plan.
} 
into the business. The Supreme Court in many decisions has affirmed the right of the state to engage in "almost any private business if the legislature thinks the State's engagement in it will help the general public and is willing to pay the cost of the plant and incur the expense of operation." 6

Insurance is in its purposes and effects the quintessence of mutuality. It represents the banding together of persons exposed to a common risk for their mutual self-protection. Government represents the acme of such a relationship. In it and through it are expressed the highest degree of cooperation. Government is set up for the protection of its citizens. It is in itself a mechanism of insurance whereby life, liberty, and the right to economic security are supposed to be guaranteed. Insofar as it fails to assume these, it falls short of its purpose. What could more properly be included within its scope of operations, therefore, than the carrying on of the business of insurance? Its assumption of such an activity would carry the philosophy and practice of mutualism to its ultimate goal. The state has recognized its responsibility in these matters by providing against the results of the failure of wage earners to insure, for whatever reason, by means of its systems of relief to widows and orphans, aged, and those suffering from industrial accident.

There is nothing in the life insurance business which should militate against its successful operation by the people. The usual arguments against government ownership are that it is inefficient, inflexible, lacking in skill and initiative, and bureaucratic. It is not our function or purpose to dwell on the general question. We may make the observation, however, that the conduct of government itself with its multitude of economic and social interests is no mean feat, and calls for at least as high a degree of organization and skill as any commercial enterprise.

Life insurance differs from other undertakings in the very basis of its operations. Relative to other activities it is quite simple and reducible to a definite routine. It does not or need not involve the element of risk that characterizes the usual form of private enterprise and for the bearing of which a profit is required as compensation. There is not the same possibility of loss which would have to be made up by the exaction of taxes as in certain other governmentally-operated services.

The business of life insurance comprehends actuarial, distributive, and investment operations. The actuarial basis is a matter of settled routine, which would be used by the government just as it is by the private companies. Reserves under government operation would be necessary as at present in order to guarantee payment of risks. There is no speculation here; there is no experimental advantage to be gained by private enterprise in this particular connection. Indeed, the companies may be accused of an inflexibility which might well be improved upon by government actuaries.

American life insurance companies have shown consummate skill in their development of the distributive phase of the business. It is doubtful whether in this

- Wolff Co. v. Industrial Court, 262 U. S. 522, 537 (1923), quoted in KEEZER \& MAY, op. cit. supra note $I, 185$, to which reference is made for a full discussion of the question. 
respect much more needs to be done. Indeed, the selling technique has been developed much too far-to such an extent as often to defeat the very purpose for which it has been devised. At any rate, assuming the government were to take over the business and use the same methods, the fundamentals developed under private management could certainly be adopted. It is highly questionable whether government servants would exert the same unrelenting pressure for business as have private company sales executives, and they would be deserving of the strictest censure were they to do so. Basically, however, the part of the insurance business which concerns its contact with the insuring public consists in securing or receiving application, the receiving of premiums and the payment of claims. The form of the business does not change. It is essentially the same today as it was fifty years ago. This is not so in other realms of commerce. The operation of railroads, for example, is quite another story. Engineering science has wrought radical changes in the transportation business. New forms have been developed and new areas of competition have arisen. Railroad rate making is complicated by its adjustment to new conditions, all of which requires initiative and flexibility. By comparison, however, life insurance is static. Because of its very nature, its success or failure under public auspices is not dependent in the same degree on the presence or absence of these attributes.

\section{Enhanced Security of Government Investment of Insurance Funds}

That part of private life insurance business in which risk does appear is the investment of the funds. The proper disposition of the tremendous sums of money which are constantly flowing into the coffers of the companies is a grave responsibility and requires real skill. Serious question has been raised as to how successfully that function has been performed. ${ }^{7}$ Certainly the experience of the depression does not warrant the belief that the managers of the private companies have possessed an unusual skill in picking safe investments. Many insurance companies have in fact only been saved from liquidation by government aid. They not only borrowed directly from the Reconstruction Finance Corporation but "what is apparently overlooked is that indirect assistance to insurance on a large scale was involved by the bolstering up of the concerns and institutions in which insurance funds were invested. If, for example, a loan by the R. F. C. enabled a railway to meet its bond interest, some of which accrued to an insurance company, the boasted independence of the latter is only nominal. This was seen when the official policy of liberal lending failed to overcome the depression, and the prospect of widespread internal default threatened all financial institutions with disaster. A reference to the distribution of U. S. insurance investments ... will reveal that insurance was particularly susceptible to the process of internal defaults. It was committed to farm mortgages; it had participated in the extravagant boom in urban real estate, and in the unwieldy expansion of public utilities; it had large holdings of railway securities, and had greatly increased its investment in state, county, and municipal bonds."

"Cf. Schnitman, How Safe is Life Insurance? (1933).

${ }^{8}$ Paish \& Schwartz, Insurance Funds and Their Investament (London, 1934) 103, 104. 
Under government operation, the investment risk could be practically eliminated. Concentration of the investment of premium income in its own securities would not only contribute to a simplification of its own financing but would place the funds on a more secure level, less subject to the vagaries of the business cycle, and without additional cost either to the general taxpayer or to the policyholder. Moreover it would place at the disposal of the government resources heretofore largely invested elsewhere, and, as the preceding quotation demonstrates, not always to sound social purpose. United States companies have been much less accustomed to investing in government securities than English companies. In I93r but I.9 per cent and in 1932 2.I per cent of the total admitted assets of 52 reserve life insurance companies holding more than ninety per cent of all admitted assets of legal reserve companies were placed in United States government securities. ${ }^{9}$ There are, of course, other phases of the problem which cannot be entered into within the limited space of this paper.

The cost of insurance funds to the government would not need to exceed what it is now forced to pay in the open market for long term loans, and might even be fixed at a lesser rate with consequent saving to the taxpayers on its general account. Notwithstanding this, under its management the cost to the insured could be materially lessened through methods which would make the savings due to improved mortality actually and immediately available to all policyholders and by a radical reduction in expense of conducting the business.

Altogether, however, a consideration of the various factors entering into the conduct of life insurance shows that under government monopoly the business could be conducted with no less facility, taking into account the real interests of the policyholders, and with much less risk to the insurance funds than is involved under private management. "The relative inefficiency of public operation, as compared with private operation, is very largely in highly speculative undertakings and dwindles to nothing in respect to those where the speculative element is practically non-existent."10

Contracts of insurance and annuities are for the most part long term instruments and require for their fulfilment the utmost certainty of continued existence on the part of the agency writing them. Such a desideratum in life insurance transcends that of most other negotiations. With all due respect to the soundness of United States companies as a whole, there can be no doubt that our government may be rated as the most permanent and sound of our institutions. Despite all regulations, many companies have failed with serious loss to the insured and their beneficiaries. The likelihood of insolvency is present in certain jurisdictions because of poor state insurance codes and lax administration. The federal government offers a greater guarantee than any company because it cannot be declared insolvent nor can it perish. It may pass through crises, but it recovers. Once a company fails it dis-

${ }^{9} I d$. at 67 . Recent statistics show a substantial increase in the proportion thus invested.

${ }^{10}$ Pigou, The Economics of Welfare (London, 1930) $35 x$. 
appears and irreparable loss ensues, unless it is rescued by the government or its assets and liabilities are assumed by another and stronger company. If a company fails the loss may be without any remedy. Under government auspices, payments are assured not only by the reserves that are set up, but these are also backed by the credit of the whole governmental structure. The government is the safest fiscal depository. Its bonds are the soundest form of investment. During the present crisis funds have been transferred in great volume from the banks to the postal savings department because of the assuredness of safety of the latter. Indeed, as has already been pointed out, the credit of the government had to be drawn upon to protect the community's deposits in private institutions of all sort, including life insurance companies. As sound as our great life insurance institutions are under normal conditions, their solvency had to be preserved by legislative action at the time of the banking collapse in and following March I933, and more than once has it been necessary to permit insurance companies to value their securities at higher than current levels in order to maintain a semblance of solvency.

The "run" on insurance companies which occurred during the winter and spring of 1933 served to emphasize the helplessness of private enterprise in the face of public panic. People who could not withdraw their bank deposits turned frantically to the insurance companies and found themselves defeated when a moratorium was placed on the payment of cash values. The life insurance companies do not like to have their banking function emphasized, yet they found themselves driven to a point of liquidity in order to meet their demand liabilities which threatened not only their own safety but that of many institutions dependent upon them. The resources of the nation which were rallied to their support in the hour of danger would always be present to protect the savings of the millions of policyholders were the government the insurer. The advantage of life insurance under federal control has never been so clear.

Much has been said favorable to the financial astuteness of the companies and their managers during this period because of their ability to meet their obligations at a time when other fiscal institutions failed. But when one examines the figures, their performance is not necessarily so great. Private business suffered seriously, because of its inability to "turn around." It found its cash reserves locked up in closed banks and/or was unable to secure necessary credit. The result was that many going concerns were wiped out or seriously crippled. Life insurance companies were in a much better condition, and for a long time were almost the only source of cash. The reason for this was not the brilliance of their administrators, but rather the nature of the business which brought to their doors a constant stream of cash in the form of premium payments. From I930 to I932, forty-eight companies holding 86.4 per cent of admitted assets of all United States companies had a cash income from premiums, interest, dividends, and rents of $978 \mathrm{I}$ millions of dollars. Their total cash payments to living policyholders by way of policy loans, matured 
endowments, surrenders, dividends, and other payments plus payments of death claims totaled 6r70 million dollars. Their expenses reached an outside total of 2 billion dollars still leaving them a substantial margin of cash. ${ }^{11}$

\section{Social Advantages of Government Control of Insurance Funds}

The relationship between life insurance companies and banking is very close, much more so than the general public suspects. The recent Senate banking investigation only scratched the surface, but sufficiently to arouse curiosity as to the extent of the connection. The suspicion that has been engendered is not a healthy one and for the sake of reëstablishing public confidence the inquiry should be continued in order that the facts may become known. The companies themselves should be the first to insist that this be done. The dependence of the millions of policyholders, large and small, on the sound financial reputations of the companies makes it unwise, as a matter of sound public policy, that any tinge of inimical fiscal practice, such as has been exposed on the part of bankers, should attach itself to life insurance institutions.

There is much uneasiness over the tremendous power possessed by the insurance companies because of the fabulous resources at their command. A direct obligation rests on the executives of these organizations to apply these funds to the broadest public and social service. Unless properly managed this power constitutes both an actual and potential menace to the freedom of our institutions. Policyholders are numerous enough to constitute nearly the entire nation and it is important that the formidable accumulation of wealth, which is made up of the myriad individual contributions in possession of the companies should not be used against the best interests of the policyholders. The history of life insurance has shown that this has not always been so. Company funds have been used to block proposals in the public interest, thus creating the anomalous situation of the people's own money being employed against them. This was quite obviously illustrated in the blocking of efforts at social insurance in this country, or, as in England, in the emasculation of the health insurance legislation as a condition of its passage. While it may be considered natural that the managers of companies should oppose legislation which would tend to curtail their own operations, it raises the serious question as to whose interests are paramount. Under such circumstances there can be no question that, in the hands of the government, insurance funds would be more democratically employed. Management, whether in mutual or stock companies, ultimately rests in the control of a small coterie of individuals. Except in cases of disclosed flagrant abuse, they are subject to no one's will but their own.

State regulation of investment practice exists only within broad and well-defined limits. There is no scrutiny of details which may be subversive or not entirely in the social interest. Under government control, the operations of the insurance department would be more directly of public concern. The people through their

IN PAISH \& SchWarTz, op. cit. supra note 8, 102. 
legislative representatives and the press would be quick to sense and rectify wrongs. In the long run the danger to the public from politics is much less than control behind the scenes which may extend far beyond the immediate field of insurance into almost every phase of our national life, public and private, and which may even affect the very safety of the republic itself. The disclosures of the past two years in other directions prove that this is no idle dream.

Under government operation such profits as might result would definitely be used in the public interest and in such a way as to improve the conditions and standard of living of the people as a whole. An example of how such funds are used is to be seen in the Japanese experience. Japan has a monopoly of the system of industrial insurance in that country. "It was monopolized by the government with a view to keeping it clean from the evils which may result from keen competition when left in the hands of private undertakings." It is sold through more than 8000 post offices scattered throughout the land and although proprietary in form, the fund is kept separate from the general account of the Treasury, and the policyholder has a share in the surplus without discrimination or special favor. The funds are invested in their place of origin in the exact proportion in which such place has contributed towards the formation of the fund and are restricted to social welfare works of many kinds. ${ }^{12}$

\section{Elimination of Competitive Evils Through Government Operation}

Under a system of nationalized insurance not only will the proceeds be more definitely directed to the benefit of the policyholder, but his interests as a purchaser will be considerably enhanced. Standards of distributing life insurance as in most commodities and services have been developed from the producers', the sellers' point of view, rather than from the angle of service to the consumer on his beneficiaries. Under the extreme competitive conditions of today the business is surrounded with an air of mystery that is wholly artificial. The applicant for insurance is generally an ignorant buyer. The few simple facts that he might be taught in order properly to satisfy his needs are rendered unduly complex by the multiplicity of contracts that are displayed before him and which are devised largely as sales tidbits and which do nothing more than confuse, increase the cost, and render fulfilment of their conditions more difficult. Under a non-competitive governmental plan there would be no need for all this. The number of types of policies could be radically reduced. Shopping around between companies is almost an insuperable task for the purchaser today. He becomes confused by technicality upon technicality, and may end up with the wrong thing more likely than not. The hall-mark of government insurance would be simplicity. It would make possible the provision of a more uniform type of service, policy, and cost.

Competition in life insurance has brought some benefits to the policyholder but it has caused infinitely more damage. The real reforms and advantageous policy con-

${ }^{2}$ See the writer's Social Cost of Industral Insurance (1933) 326. 
ditions have been made generally available if not actually achieved through legislation. Competition has served mainly to advance and improve them a little further. Beyond this, private ingenuity has been exercised too largely in the direction of devising more complex forms of contracts to act as a public appetizer for more insurance. The next real advance lies in the possibility of extending its benefits to all of the people and at a much lower cost. This is only possible under government operation.

Public monopoly would reduce cost through the elimination of many of the results of competition which now increase company expense. The reduction would be experienced both in the immediate lowering of premium charges and in the saving of the policyholders and the country at large from the tangible economic and social wastes due to the immoral and unethical practices of overselling, improper selling, rebating, and twisting, and, above all, from the enormous lapse rate. No one in the insurance business today denies that these are all real evils. The literature is full of suggestions for eliminating them. Insurance commissioners are forever warning companies and agents, individually and collectively, of the dire results to be expected from their continuance. And yet there is no appreciable improvement. In fact, depression conditions have made matters worse. The flood of agents roaming the length and breadth of the land seeking prospective policyholders have descended to practices that have given insurance officials, public and private, grave concern. Human nature does not change; it is the system that must be changed. There is no room for argument as between the quantitative results of an agency and a non-agency system. America leads the world in insurance coverage because of its concentration on the production side of the business. But the price that the nation as a whole has had to pay in waste has been correspondingly large, and the price has been too great. This has been especially true in the domain with which this symposium is mainly concerned, namely, life insurance among the lower income classes. The writer need not dwell too long on the damage wrought among this group by the system of industrial insurance. He has treated this fully elsewhere. ${ }^{13}$ The only real substitute for this class of insurance is government monopoly.

Interesting testimony has recently been offered showing the net difference in results between systems in which insurance is bought and the more prevalent one in which it is sold. Mr. Rainard B. Robbins in an article in The Survey ${ }^{14}$ writes as follows:

"During the year 1932 the preparation of more than a million life insurance policies at a cost of from $\$ 5$ to $\$ 10$ each proved to be waste effort because premiums to place the insurance in force were never paid. During the same year ordinary life insurance policies (individual policies other than industrial) to the extent of 60 per cent of the amount of new business issued during the year lapsed without value for non-payment of premiums.

-..

23 TAYLOR, op. cit. supra note 12.

14 Robbins, Life Insurance That Lives (July, 1934) 70 THE SURveY 216-217. 
"Comparison was first made with thirty-six life insurance companies that might be called contemporaries, as they began business in the years rgrI-20 inclusive. In I 922 the amount of life insurance in force in these agency companies was on the average nearly twice as large as with the Teachers [Teachers Insurance and Annuity Association of America]. During the next ten years also the average amount issued annually by the thirty-six companies was more than twice as large as that of the non-agency company; yet in 1932 , at the end of the decade, their insurance in force averaged less. Otherwise stated, the non-agency company increased its business 83.7 per cent of its new insurance; the agency companies, only 25.7 per cent.

"Similar data were then obtained for five large mutual companies doing neither an industrial nor a group insurance business, the youngest of this quintet having begun business in 1858 . The increase in insurance in force for the five mutuals averaged 40.3 per cent of the issues for the ten-year period (against 83.7 per cent in the non-agency company)....

"Comparison was next made with the life insurance written by savings banks of Massachusetts. Any citizen of Massachusetts may apply for $\$ 1,000$ of insurance with each of the twenty-one banks that have established insurance departments. During the ten year period of comparison, the increase in insurance in force in the Massachusetts Savings Banks was 82 per cent of issues, a figure so closely approximating that of the Teacher's lcompany as to create a strong presumption that the favorable economic status of the policyholders in the latter was not what accounted for the persistency of their policies. Clearly when persons drawn from a fair cross-section of our population buy life insurance 'over the counter,' they buy it to keep."

There would not be the same stimulus to "production" under a voluntary system of nationalized insurance whether with or without agents. Government agents on either side of the counter would not be interminably driven to sell, sell, sell, regardless of the need or ability to maintain insurance. Incentive to excesses and various forms of malpractice would be absent. They would not constitute the routine of a large part of the force as a means of holding a job. Indeed, there would not be so many agents. Too many solicitors in the field "chiseling" for a living is what makes bad matters worse. Those chosen would even under a minimum standard of civil service be, on the average, far better prepared to pursue their calling than life insurance agents today.

\section{Economies Possible under Government Operation}

The shifting of emphasis away from "production" and salesmanship under government operation would, as we have shown, mean better service to the policyholder. It would also mean cheaper insurance. It would not be necessary to spend from fifty to more than one hundred per cent of the first year's premium to secure new business. Older and persistent policyholders would not have to be taxed for the purpose of raking in millions of new prospects who either do not come in at all or do not remain in long enough even to compensate for the expense of getting them in. A recommendation such as we shall later make for a system of government insurance to include the possibility of a subsidy for part of the insured will no doubt be considered heretical, and yet what we have now is exactly that in its worst form. 
No one benefits under it. Indeed all are the losers, either financially or morally. Under a plan of government insurance which might include payment of all or part of the premium for those who could not afford it, there would be a distinct gain not only to those insured but to the taxpayers at large in the ultimate saving of relief disbursements.

This has been said on the assumption that a government plan would include the use of agents as in New Zealand. The reduction in cost would be even greater were there no agents or under a system of compulsory insurance. The agency system of today includes not only too many agents in the field with their necessary complement of supervisors, inspectors, etc., etc., but also a swollen army of middlemen. No official bureaucracy could ever be set up to manage a national organization which would approach, let alone exceed, the present number operating our private agencies. The saving in personnel through consolidation into one national scheme would, of course, extend to the administrative as well as the sales force. There would be no necessity for several hundred regional bureaus corresponding to the number of our present companies and their branches.

This would lead to a material saving in the housing of the insurance department. Companies have been quite conspicuous in their race to outdo each other in the erection of palatial home office buildings. In common with their other real estate investments in recent years, the possession of these magnificent buildings has served to reduce the policyholders' assets. Both for home and branch offices, government property could be used at a substantial saving.

The cost of salaries to administrative officers would be radically less. There has been much criticism on this score during the past few years, and to state that a reduction of a $\$ 200,000$ or a $\$ 150,000$ salary would make no difference in the cost of insurance to the policyholder constitutes no answer. Unquestionably a doubling of these salaries would not cause any increase in premiums either. It is all a matter of what any man's services are worth, and what he needs to be paid to stimulate him to his best efforts. Government salaries are notoriously low and public service suffers for its unwillingness to compete with private concerns in the matter of compensation. Were there no attraction away from government employ, these same men who are competent enough to be offered more substantial emolument under private auspices would remain with the government and the public would continue to be the beneficiary of their skill.

Life insurance under public ownership would cost less through the elimination of taxes as an expense. The multiplicity of taxing bodies throughout the country now derive a substantial revenue from the companies. According to the 1932 report of the New York Insurance Department, the total disbursements of all life companies licensed to do business in that state amounted to 3,099 million dollars. The total disbursements other than those paid to policyholders were 768 million dollars of which taxes of all kinds totaled nearly $7 \mathrm{I}$ million dollars, or nine per cent of the overhead 
expense. Taxes also constituted 2.3 per cent of premium payments. This is a substantial proportion considered from either point of view. Such revenue would have to be drawn from other and perhaps more equitable sources. The gain to the total body of policyholders, however, would be greater than the proportionate loss to each of the 48 states and the federal government. Moreover, there is considerable opposition to taxes on life insurance funds as a penalty on thrift, and there is justice in this view particularly when the assets are those of policyholders in a mutual company.

We have already referred to savings to be made through a revision of the mortality table. The one now in general use for determining reserves and by mutual companies, at least, for fixing gross premiums, is based on the experience of one company in the middle of the nineteenth century. Due to advances in the science of public health the death rate has been substantially reduced. The average expectancy of life has been sharply increased. During the past twenty-five years the actual mortality experienced by the policyholders has, with the exception of the pandemic year of Igr8, ranged between fifty to seventy per cent of the expected mortality in the table. Even in the unusual year of 1918 it failed to reach the expected by more than three per cent.

The ultra-conservation of the companies is claimed to be offset by applying the gains from mortality to the payment of dividends in mutual companies. There are, of course, also gains from interest and loadings, although the latter also frequently show a loss which has to be made up from the other two accounts, and which would not be necessary under government operation. However, mortality gains used to reduce gross cost through a payment of dividends are of no value to the new policyholder. He still is forced to pay a much higher premium than would be necessary were a lower, though actuarially sound, table used. Under the latter, his dividends would be less were he to continue. Were he not able to do so, which is the case with so many, he would not be as great a loser as he is now. This is quite possible of achievement under private management. It would be much more likely of accomplishment under public auspices which, with the tremendous resources at its command through the combined control of all insurance and the greater stability of its consolidated mortality experience, all backed by the great credit of government, could more easily undertake to experiment with a more realistic base of calculations. We are not suggesting that the federal insurance authority should use other than insurance funds to meet its insurance obligations. We do not believe that it would be called upon to do any such thing, but it would not be tied down by the sort of inertia that now exists among private companies who zealously guard their surpluses against contingencies which are not likely to occur.

Perhaps the most substantial opportunity for reducing the cost of life insurance to the masses would arise out of the extension of the group principle under government operation. Group insurance as at present conducted is offered almost solely to groups of employees under an annually renewable term contract at an average cost 
of about ten dollars per thousand of insurance for all regardless of age or physical condition. This is pure protection, the savings part of the premium being eliminated. It is written without medical examination, all being accepted regardless of physical condition, providing at least 75 per cent of those employed adopt the plan. Underwriting costs are reduced to a minimum because of the participation of the employer in collecting and paying premiums.

Such cheap protection could be extended to the entire American people under a plan of compulsory national insurance. Because of the exceedingly wide spread of risk and the assuredness of stability of average age and physical condition there would be an ideal insurance set-up. No medical examinations would be necessary and rates would be the same for all regardless of age. Premiums would be deductible from wages of those employed by others, with provision made for keeping insurance in force of those out of employment, as, for example, through a special reserve created out of a slight increase in the premium rate. A compulsory scheme would probably be necessary, apart from other reasons, in order to prevent overloading the system with less-than-average risks.

Private insurance today fails in that it cannot protect those that need it mostthe physically unfit and the economically insufficient. It must confine itself to the select risks though the effects of non-insurance strike all classes. The selection arises, in addition, through the factor of high cost. Under such a plan as we suggest both these obstacles would be removed. The government, which is ultimately the insurer of us all, could become the immediate underwriter with both material and moral benefit to its constituents, individually and collectively. Such a plan of compulsory contributory insurance might very well constitute the foundation stone of a comprehensive system of nation-wide social insurance.

\section{Discriminations Eliminated under Government Operation}

Government operation would provide a uniformity the lack of which under private auspices costs a large body of policyholders considerable sums of money on the one hand and deprives an even larger number of valuable privileges on the other. The hall-mark of private enterprise as a general proposition is found in its ability to attack different problems differently and to treat varying conditions arising out of dissimilarities whether of geography, seasons, and so forth, according to their particular needs. This advantage has little if any application to the field of life insurance. Such differences as may exist are as likely to be found in one place as in another and at one time as at another. They cut across the whole population regard. less of location. Differentials in treatment are national and uniform. The quintessence of life insurance, therefore, is uniformity made possible by the law of great numbers and required by the law of averages as a condition of solvency.

The lack of it between companies would be removed under nationalization. For example, there would be homogeneity in interest rates on loans and on less-thanannual premiums. There would be an absence of such discrimination as we now 
have between policyholders of the same company in different states on the matter of dividends, due solely to lack of uniformity in interpretation by insurance officials. Furthermore, there would be an absence of the differential treatment of policyholders such as exists between the ordinary and the industrial branches of the business, as well as between various groups in the latter alone. The industrial companies have been able to secure for themselves blanket exemptions from the policy provisions laid down for ordinary policyholders. Space does not permit the recounting of the details. ${ }^{15}$ Suffice it to say that this merely adds to the hardships of the holders of this form of contract.

Depending also on the company and the state within which it is incorporated, there are gross differences in the rights afforded by the industrial policy. This is very well illustrated in the matter of cash values. The period following which they may be secured ranges from three to twenty years to none at all at any time. Such discrimination would not be possible under national control.

\section{Government Operation and Individual Liberty}

The change from private to government insurance would not constitute a radical step from the point of view of the policyholder. Since the state already controls the companies very closely in many of its phases, such as the regulation of reserves, policies, etc., the step to monopoly would involve no great change from the point of view of the liberty of the individual insured. There is in fact considerable of the element of monopoly in present company practices. The only real freedom which exists now is the choice of company in which to insure. Taking over the business by the government would mean, not considering the other advantages already pointed out, merely a different agency of distribution. The curtailment of that degree of liberty involved in freedom to choose the company would be more than offset by the social and moral advantages of state protection.

The individual as a consumer does not possess the freedom or power in relation to the service he buys in insurance that he does in other aspects of his daily existence. $\mathrm{He}$ is in effect subject to the same price control that is characteristic of the public utility monopoly. Indeed, he has greater control over the cost of gas, electricity, and transportation than of insurance. The rates of these commodities are subject to public regulation and they are sometimes reduced when popular demand shows the justice of the change. State regulations of life insurance does not extend to the size of premiums.

There is no equating of supply and demand in insurance. Its price has no real relation to either. As stated by the Supreme Court, it "is not fixed over the counters of the companies by what Adam Smith calls the higgling of the market, but formed in the councils of the underwriters, promulgated in schedules of practically con-

${ }^{25}$ TAYLOR, op. cit. supra note 12. See also Regulation of Industrial Insurance, Hearing before the Subcommittee on Insurance and Banks of the Committee of the District of Columbia on S. 1903, A Bill for the Protection of Industrial Insurance Policyholders in the District of Columbia, 71st Cong. 3rd Sess. Dec. Ig, I930. 
trolling constancy which the applicant for insurance is powerless to oppose."16 The purchaser of life insurance is almost always an ignorant purchaser without any intelligent knowledge either of his needs, the best means of satisfying them, or the source of their fulfilment. The insurance contract while between two parties is not drawn in the usual manner as between two entities of equal strength. The applicant's choice is between taking the policy or not. He has no part in determining its conditions. He finds them fixed for him in advance. There are other features of similar import which need not be developed for our present purpose. Suffice it to say that they have all the earmarks of monopoly. The intense competition between the companies is on a different level from other economic enterprises. It does not yield the consumer the same degree of benefits-indeed, as we have already shown, the reverse may be true. There is, therefore, not the same objection to government participation as might be argued in other fields.

The question of monopoly is also of interest with respect to the method of government operation. Should the state undertake life insurance exclusive of all others or should it enter into competition with the existing institutions? The problem is a difficult one, and a full discussion of it would extend this paper to an undue length. We believe that best results would be achieved under federal monopoly. Competition between government and private enterprise is an anomaly. It is unfair to both. If there is sound reason for governmental operation of an industry, it should logically carry the matter the full distance. Competition between state and private undertakings may develop a rancor which can only serve to undermine confidence in the whole governmental structure due to the efforts to discredit public operation by those in the private field who naturally seek to advance their own cause. There are set up currents of dissatisfaction and repercussions in other directions which, to say the least, are not healthy even though the basis of them may be untrue.

Ways and means of government ownership without operation have been devised through independent corporations under public control as a means of eliminating one of the so-called drawbacks of government participation. ${ }^{17}$ Details of effecting the fundamental purpose are worthy of discussion, but cannot be undertaken here. State regulation, however, does not always accomplish the ends that are better achieved under monopoly. Bitter experience in the workmen's compensation field testifies to this. We have also seen the unfortunate effects of judicial decisions in vitiating attempts at equitable regulation, particularly in the public utility field. The result is nothing less than confusion.

Finally we believe that only under government monopoly could there be carried out a scheme of compulsory insurance. All are agreed that protection should be

\footnotetext{
${ }^{13}$ German Alliance Ins. Co. v. Kansas, 233 U. S. $389,4 I 6$ (I9I3). Quoted in KeEzer \& Max, op. cit. sipra note I, 105.

${ }^{27}$ Separate Statement of Joseph B. Eastman, Report of Committee on Public Ownership and Operation, Nat. Ass's, Railroad and Utimity Comm'rs, 39th Ans. Conv., 1927, 336 et seq.
} 
universal. The question is, how may that happy state be achieved without the present high cost and social and economic waste? Experience has shown that too large a share of the population will not insure without pressure, and therein lies the raison d'être of the agent. Unfortunately, at least half the population is in no position financially to purchase any insurance. Therein lies the basic fallacy of the whole industrial insurance movement. It seeks to cover the low income class with a type of insurance which is inadequate even for its expressed purpose of providing burial, at a prohibitive cost, and by methods which are to be condemned as contrary to sound public policy. The most that can be said for it is that it is the best of a lot of bad bargains offered the workingman in the field of life insurance. But why have any bad bargains at all? For the poor and for the improvident, the only sure method is one of government compulsion at a cost which will be within their reach. This implies one of two things: either that all should be assured of a living wage with a sufficient margin over and above the minimum necessary for a decent standard of living from which premiums can be paid, or that for those not receiving such a level the government should provide insurance without cost, the funds for which should be taken from the general treasury.

It is not our intention to discuss the details of such a plan which would include the amount of insurance, the age at which it should be entered, and so forth. The principle is sound and its accomplishment urgent. We pay for the lack of it through our costly and ineffective system of public poor relief. If the thought of compulsion is obnoxious to our American ideas, the alternative is even worse. No sane or sound thinking individual who knows the facts could for a minute argue against insurance benefits as a matter of right as compared with our miserable and costly inadequate dole system. Compulsory social security is no more at variance with our philosophy of life than compulsory education or sanitation.

While the benefits of a compulsory system would accrue primarily to the poor, the middle and upper classes would also benefit directly and indirectly. They would get their protection cheaper and their insurance investments, no matter how large, would be safe beyond cavil. From the benefits that would be universally spread among the poor they would also derive a full measure of satisfaction and a sense of well-being. Not the least of the advantages to result would be a greater measure of safety of our institutions which are jeopardized in proportion as there exists misery and discontent.

Collaterally, the benefits of a system of compulsory life insurance can be incorporated into a general plan of social insurance for that part of the population which would be included under it. The premiums may be combined with those which will purchase protection against unemployment, old age, ill health, burial expense, and the rest. A tripartite scheme of contribution by the insured, the employer, and the government would make possible a greater volume of benefits to the workingman and his family while leaving him with a correspondingly larger share of his current income for present enjoyment. 